\title{
Two levels of the inspired oxygen fraction in propofol-anesthetized dogs with high intracranial pressure: cardiopulmonary function
}

\author{
[Dois níveis de fração inspirada de oxigênio em cães anestesiados com propofol e com pressão \\ intracraniana elevada: função cardiopulmonar] \\ P.C. Ferro Lopes ${ }^{1}$, N. Nunes ${ }^{2}$, E.A Belmonte ${ }^{1}$, R. M. Almeida ${ }^{1}$, L.G.G.G. Dias ${ }^{1}$, \\ G.B. Pereira Neto ${ }^{1}$, A.L.G. Souza ${ }^{1}$ \\ ${ }^{1}$ Aluno de pós-graduação - Faculdade de Ciências Agrárias e Veterinárias - FCAV-Unesp- Jaboticabal, SP \\ ${ }^{2}$ Faculdade de Ciências Agrárias e Veterinárias - FCAV-Unesp- Jaboticabal, SP
}

\begin{abstract}
In the initial stage of traumatic brain injury, the use of 1.0 inspired oxygen fraction $\left(\mathrm{FiO}_{2}\right)$ is indicated. However, high $\mathrm{FiO}_{2}$ has been correlated with atelectasis. Thus, the effects of $\mathrm{FiO}_{2}=1.0$ and $\mathrm{FiO}_{2}=0.6$ on the cardiopulmonary function in propofol-anesthetized dogs with high intracranial pressure (ICP) were evaluated. Eight dogs were anesthetized on two occasions, receiving, during controlled ventilation, an $\mathrm{FiO}_{2}=1(\mathrm{G} 100)$ or an $\mathrm{FiO}_{2}=0.6(\mathrm{G} 60)$. Propofol was used for induction $\left(10 \mathrm{mg} \cdot \mathrm{kg}^{-1}\right)$ followed by a continuous rate infusion $\left(0.6 \mathrm{mg} \cdot \mathrm{kg}^{-1} \cdot\right.$ minute $\left.^{-1}\right)$. An increase in the ICP was induced by temporary obliteration of the right jugular vein $\left(\mathrm{OJ}_{\mathrm{v}}\right) 50$ minutes after induction of anesthesia. The measurement was taken twenty minutes after $\mathrm{OJ}_{\mathrm{v}}(\mathrm{T} 0$ ) and then at 15 -minute intervals ( $\mathrm{T} 15$ to $\mathrm{T} 60$ ). Alveolar oxygen partial pressure in G60 was lower than in G100 during the whole procedure. Alveolar-arterial oxygen gradient in G100 was greater than in G60 at T0 and at T60. No differences were observed for arterial oxygen partial pressure/inspired oxygen fraction ratio, arterial-to-alveolar oxygen pressure ratio, respiratory index, venous admixture, oxygen delivery, oxygen consumption, oxygen extraction, heart rate, mean pulmonary arterial pressure, pulmonary arterial occlusion pressure, cardiac index, stroke index and systemic vascular resistance index. In G100, mean arterial pressure at T0 was higher than at T45. In dogs with high ICP, the cardiopulmonary function was not influenced by the different $\mathrm{FiO}_{2}$ used.
\end{abstract}

Keywords: dog, total intravenous anesthesia, cerebral autoregulation, hemodynamic, venous admixture

\section{RESUMO}

No estágio inicial do trauma encefálico, o emprego de fração inspirada de oxigênio $\left(\mathrm{FiO}_{2}\right)$ de 1,0 é indicado. Todavia, altas $\mathrm{FiO}_{2}$ têm sido correlacionadas com atelectasia. Assim, avaliaram-se os efeitos das $\mathrm{FiO}_{2}=1.0$ e $\mathrm{FiO}_{2}=0.6$ sobre a função cardiopulmonar em cães com pressão intracraniana (PIC) elevada e anestesiados com propofol. Oito animais foram anestesiados em duas ocasiões e receberam, durante a ventilação controlada, $\mathrm{FiO}_{2}=1(\mathrm{GlO0})$ ou $\mathrm{FiO}_{2}=0,6(\mathrm{G} 60)$. Propofol foi usado para indução $\left(10 \mathrm{mg} \cdot \mathrm{kg}^{-1}\right)$ e seguido por infusão contínua $\left(0,6 \mathrm{mg} \cdot \mathrm{kg}^{-1}\right.$ minuto $\left.{ }^{-1}\right)$. O aumento da PIC foi induzido pela obliteração temporária da veia jugular $\left(O J_{v}\right)$. As mensurações foram realizadas 20 minutos após $O_{v}$ (T0) e em intervalos de 15 minutos (de T15 a T60). A pressão parcial de oxigênio alveolar no G60 foi menor do que no G100 durante todo o procedimento. O gradiente alveolar-arterial no G100 foi maior do que no G60, em T0 e T60. Não foram observadas diferenças para: relação pressão parcial de oxigênio/fração inspirada de oxigênio, relação arterioalveolar, índice respiratório, mistura arteriovenosa, oferta de oxigênio, consumo de oxigênio, taxa de extração de oxigênio, frequência cardíaca, pressão da artéria pulmonar média, pressão de oclusão da artéria pulmonar, índice cardíaco, indice sistólico e índice de resistência vascular sistêmica. No G100, a pressão arterial média em T0 foi maior do que em T45. Em cães com alta PIC, a função cardiopulmonar não foi influenciada pelas diferentes $\mathrm{FiO}_{2}$ empregadas.

Palavras-chave: cão, anestesia intravenosa total, autorregulação cerebral, hemodinâmica, mistura arteriovenosa

Recebido em 14 de fevereiro de 2013

Aceito em 16 de dezembro de 2013

E-mail: ferro_patricia@ig.com.br 


\section{INTRODUCTION}

Normal intracranial pressure (ICP) in dogs is 5 to $12 \mathrm{mmHg}$, similar to that of humans for whom $20 \mathrm{mmHg}$ is an arbitrary upper limit beyond which treatment for ICP may be instituted. Causes of intracranial hypertension can be nonvascular (interstitial edema, intracellular swelling, masses or obstruction of cerebrospinal fluid) or vascular, which include cerebral vasodilatation caused by increased arterial partial pressure of carbon dioxide $\left(\mathrm{PaCO}_{2}\right)$, distention of cerebral vessels or venous outflow obstruction (Sturges and Lecouteur, 2009).

In the initial stage of traumatic brain injury, the use of 1.0 inspired oxygen fraction $\left(\mathrm{FiO}_{2}\right)$ is indicated (Falcão et al., 2006). However, during anaesthesia, high $\mathrm{FiO}_{2}$ has been correlated with atelectasis (Hedenstierna et al., 1989), which can cause $\mathrm{PaCO}_{2}$ increase (Haskins, 2007) that can interfere with cerebral blood flow (Falcão et al., 2006) and promote the impairment of cerebral autoregulation (Häggendal and Johansson, 1965; McCulloch et al., 2000).

In several investigations, atelectasis formation with subsequent pulmonary shunting was shown to be related to impairment of gas exchange (Brismar et al., 1985). Thus, a low $\mathrm{FiO}_{2}$ has been advocated to avoid pulmonary collapse (Magnusson and Spahn, 2003).

The hypothesis was that a $\mathrm{FiO}_{2}=1.0$ has a detrimental effect on pulmonary gas exchange and can aggravate intracranial hypertension. Thus, this study was designed to establish the effects of two different levels of $\mathrm{FiO}_{2}$ (1.0 and 0.6) on the cardiopulmonary function in propofol-anesthetized dogs with a high ICP.

\section{MATERIALS AND METHODS}

This study was approved by the regional Institutional Ethics and Animal Welfare Committee (Ref: 003933-07). After the study the animals were available for adoption.

Eight adult mongrel dogs weighing $10.1 \pm 2.0 \mathrm{~kg}, 4$ males and 4 females, were enrolled in the study. All animals were determined to be healthy based on clinical and laboratorial evaluation. Blood, urine, electrocardiogram and thoracic radiography exams were all done. They were provided with water and regular dog food and kept in individual cages at the Veterinary Teaching Hospital.
The dogs were anesthetized in 2 occasions, $21 \mathrm{~d}$ apart, and received oxygen at an $\mathrm{FiO}_{2}$ of 1.0 (G100) or $0.6(\mathrm{G} 60)$ in a randomized cross-over study.

Anesthesia was induced with $10 \mathrm{mg} \cdot \mathrm{kg}^{-1}$ of propofol (Fresofol 1\%, Fresenius Kabi Brasil Ltda, Campinas, SP, Brazil) administered intravenously (IV). After endotracheal intubation, the dog received oxygen at the assigned $\mathrm{FiO}_{2}$ and a flow of 30 or $50 \mathrm{~mL} \cdot \mathrm{kg}^{-1} \cdot$ minute ${ }^{-1}$ through an anesthetic circuit (Ohmeda - Excel 210SE, Madison, EUA Proc. FAPESP 97/10668-4), that allowed partial rebreathing of gases, equipped with pressure/volumetric ventilator (Ohmeda). The oxygen concentration was checked using gas equipment (DX 2010LCD, Dixtal, Manaus, AM, Brazil - Proc. FAPESP 02/04625-0). Controlled ventilation began immediately, and the respiratory rate was adjusted to maintain end tidal carbon dioxide $\left(\mathrm{ETCO}_{2}\right)$ between $35-45 \mathrm{mmHg}$. $\mathrm{ETCO}_{2}$ was monitored using a respiratory monitor (DX 8100, Dixtal, Manaus, AM, Brazil - Proc. FAPESP 03/11125-7). Adjustments were made in ventilation before the first measurement and, consequently, before intracranial hypertension induction and no more adjustments were made thereafter.

Anesthesia was maintained with a continuous rate infusion (CRI) (Infusion Pump 670T, Samtronic Ltda, São Paulo, SP, Brazil - Proc. FAPESP 03/11125-7) of propofol at a rate of $0.6 \mathrm{mg} \cdot \mathrm{kg}^{-1} \cdot \mathrm{minute}^{-1} \mathrm{IV}$. The propofol dose was obtained from previous studies. Additionally, lidocaine (Xylestesin 2\% - Cristália Produtos Químicos Farmacêuticos Ltda - Itapira, SP) infiltration was performed on the right cerebral cortex and the right cervical region.

The dogs were positioned on left lateral recumbency. For assessment of the ICP, a fiberoptic catheter (Monitor de temperatura-pressão intracraniana, 110-4BT - Integra Neur Camino Labs, San Diego, EUA - Proc. FAPESP 00/010843) was surgically implanted on the surface of the right cerebral cortex using an access kit (Integra Neur Camino Labs - Proc. FAPESP 00/01084-3), according to the technique described by Bagley et al., (1995). An intra-arterial catheter was then placed on the right dorsal pedal artery to assess the mean arterial pressure (MAP) and to obtain arterial blood, in order to evaluate blood gas variables (Roche Omi C blood gas analyzer, Roche Diagnostics GmbH, Mannheim, Germany). Before the beginning of each experiment the pressure transducer was checked against a mercury manometer. The zero reference point was at the level of the costochondral junction. 
From these data, the following parameters were calculated:

$\mathrm{PAO}_{2}=\left[\mathrm{FiO}_{2} \times(\mathrm{Pb}-47)\right]-\left(\mathrm{PaCO}_{2} / \mathrm{RQ}\right) ;$ where $\mathrm{PAO}_{2}=$ alveolar partial pressure of oxygen, $\mathrm{Pb}=$ barometric pressure, $\mathrm{PaCO}_{2}=$ arterial partial pressure of carbon dioxide and $\mathrm{RQ}=$ respiratory quotient, which was assumed equal to 0.8 .

$\mathrm{AaDO}_{2}=\mathrm{PAO}_{2}-\mathrm{PaO}_{2}$; where $\mathrm{AaDO}_{2}=$ Alveolar-arterial oxygen gradient and $\mathrm{PaO}_{2}=$ arterial partial pressure of oxygen.

$\mathrm{RI}=\mathrm{AaDO}_{2} / \mathrm{PaO}_{2}$; where $\mathrm{RI}=$ respiratory index .

Calculation of the $\mathrm{PaO}_{2} / \mathrm{FiO}_{2}$ ratio and the arterial-to-alveolar oxygen tension ratio $\left(\mathrm{PaO}_{2} / \mathrm{PAO}_{2}\right)$ were also carried out.

Subsequently, a thermodilution catheter (SwanGanz mod 1325 French; Edwards Lifesciences, Irvine, California, USA) was introduced surgically into the femoral vein and advanced into the lumen of the pulmonary artery in order to evaluate cardiac output (CO), which was measured directly by the thermodilution technique with a microprocessed device (Dixtal mod. DX 2010, CO module, Manaus, AM, Brazil - Proc. FAPESP 96/02877-0). The catheter's position was confirmed by observation of characteristic changes in the pressure tracings as the catheter tip was advanced from the right ventricle into the pulmonary artery. Central venous pressure (CVP), mean pulmonary arterial pressure (mPAP) and pulmonary arterial occlusion pressure (PAOP) were measured via the thermodilution catheter.

Seldinger's technique to introduce the thermodilution catheter in the jugular vein was not used, because the bilateral obliteration of the jugular vein could increase intracranial pressure excessively and promote irreversible damage.

The oxygen delivery $\left(\mathrm{DO}_{2}=\mathrm{CaO}_{2} \times \mathrm{CO} \times 10\right.$, where $\mathrm{CaO}_{2}=$ oxygen content of arterial blood), the cardiac index $(\mathrm{CI}=\mathrm{CO} /$ body surface area $)$ and systemic vascular resistance index [SVRI = (MAP - CVP) x 80/CI] were calculated.

Heart rate (HR) was calculated from the simultaneous lead II electrocardiogram. The stroke index (SI) was calculated by $(\mathrm{CO} / \mathrm{HR}) /$ body surface area.

Venous blood was obtained from the thermodilution catheter's main branch to evaluate blood gas variables. From these data, the following parameters were calculated:

Qs/Qt $=\left[\left(\mathrm{CcO}_{2}-\mathrm{CvO}_{2}\right) /\left(\mathrm{CcO}_{2}-\mathrm{CaO}_{2}\right)\right] \mathrm{x} 100$ where $\mathrm{Qs} / \mathrm{Qt}=$ venous admixture, $\mathrm{CcO}_{2}=$ oxygen content of end-capillary blood and $\mathrm{CvO}_{2}=$ oxygen content of mixed venous blood.

$\mathrm{VO}_{2}=\mathrm{avDO}_{2} \times \mathrm{CO} \times 10$ where $\mathrm{VO}_{2}=$ oxygen consumption and $\mathrm{avDO}_{2}=$ arteriovenous difference of oxygen content,

$\mathrm{TeO}_{2}=\mathrm{VO}_{2} / \mathrm{DO}_{2}$ where $\mathrm{TeO}_{2}=$ oxygen extraction.

Twenty minutes after implanting the fiber-optic catheter, an increase in ICP was induced for obliteration of the jugular vein. The right jugular vein was exposed surgically and subjected to a provisory ligature consisting of 2 cotton threads $3 \mathrm{~cm}$ apart. The aim of this procedure was to obtain ICP values higher than $15 \mathrm{mmHg}$. Lower values have been considered normal (Johnston et al., 1991; Plöchl et al., 1998). The ICP was measured and cerebral perfusion pressure (CPP) was calculated subtracting the ICP value from the MAP.

The first measurement of each variable was taken 20min after (T0) obliteration of the right jugular vein $\left(\mathrm{OJ}_{\mathrm{v}}\right)$, and additional recordings were performed at 15-min intervals (T15, T30, $\mathrm{T} 45$, and $\mathrm{T} 60)$.

Numerical data were subjected to one-way analysis of variance (ANOVA) to determine the difference between the different time points of the same group. Two-way ANOVA was used between groups. Bonferroni test was used for post-hoc multiple comparisons at a $\alpha$ level of 0.05. Analyses were performed using Prism 5 for Windows (GraphPad Software Inc, CA, USA).

In the recovery of anesthesia, the dog's wounds were covered with sterile bandages. Between anesthesia procedures animals were provided with water and regular dog food and kept in individual cages. Dogs were given carprofen (Rimadyl, 25mg; Pfizer, Guarulhos, São Paulo, Brazil), $4.4 \mathrm{mg} / \mathrm{kg}$ orally once a day (SID) for $3 \mathrm{~d}$, and benzathine penicillin $\mathrm{G}$ (Billi Farmacêutica, Santo Amaro, São Paulo, Brazil), $40.000 \mathrm{U} / \mathrm{kg}$ intramuscularly once a day for $5 \mathrm{~d}$. One person was responsible for surgical wound care, medication and taking the dog for a walk twice a day. 


\section{RESULTS}

The baseline ICP was 15 (5)mmHg for G100 and 13 (4)mmHg for G60. By 20min after $\mathrm{OJ}_{\mathrm{v}}$ (T0) the ICP had increased $46.67 \%$ in G100 and
$38.46 \%$ in G60 (Figure 1). The ICP and CPP values did not differ significantly $(\mathrm{P}>0.05)$ between $\mathrm{FiO}_{2}$ levels or between measurement times after $\mathrm{OJ}_{\mathrm{v}}$ (Table 1).

Table 1. Cardiopulmonary measurements in dogs with high intracranial pressure anesthetized with propofol and mechanically ventilated with $\mathrm{FiO}_{2}$ of 1.0 (G100) or 0.6 (G60)

\begin{tabular}{|c|c|c|c|c|c|c|}
\hline \multirow{2}{*}{ Parameter } & \multirow{2}{*}{ Group } & \multicolumn{5}{|c|}{ Times } \\
\hline & & T0 & $\mathrm{T} 15$ & T30 & T45 & T60 \\
\hline $\mathrm{PAO}_{2}$ & G100 & $616(4) A$ & $613(5) A$ & 615 (4)A & $612(5) A$ & 614 (9)A \\
\hline$(\mathrm{mm} \mathrm{Hg})$ & G60 & 348 (6)B & 346 (7)B & $345(5) \mathbf{B}$ & $347(5) \mathbf{B}$ & 349 (5)B \\
\hline $\mathrm{AaDO}_{2}$ & G100 & 95 (65)A & $70(39)$ & $82(45)$ & $83(21)$ & 99 (53)A \\
\hline$(\mathrm{mm} \mathrm{Hg})$ & G60 & 36 (14)B & $41(23)$ & 47 (19) & 45 (14) & 47 (19)B \\
\hline $\mathrm{PaO}_{2} / \mathrm{FiO}_{2}$ & G100 & $521(63)$ & $543(35)$ & $534(45)$ & $529(24)$ & $516(45)$ \\
\hline$(\mathrm{mm} \mathrm{Hg})$ & G60 & $519(27)$ & $508(32)$ & $498(36)$ & $503(25)$ & $503(34)$ \\
\hline \multirow{2}{*}{$\mathrm{PaO}_{2} / \mathrm{PAO}_{2}$} & G100 & $0.85(0.10)$ & $0.88(0.06)$ & $0.87(0.07)$ & $0.86(0.03)$ & $0.84(0.09)$ \\
\hline & G60 & $0.89(0.04)$ & $0.88(0.07)$ & $0.86(0.05)$ & $0.87(0.04)$ & $0.87(0.06)$ \\
\hline \multirow[t]{2}{*}{ RI } & G100 & $0.20(0.16)$ & $0.13(0.08)$ & $0.16(0.11)$ & $0.16(0.04)$ & $0.20(0.12)$ \\
\hline & G60 & $0.12(0.06)$ & $0.14(0.08)$ & $0.16(0.07)$ & $0.15(0.05)$ & $0.16(0.07)$ \\
\hline Qs/Qt & G100 & $21(8)$ & $21(7)$ & $23(14)$ & $28(18)$ & $27(12)$ \\
\hline$(\%)$ & G60 & $17(4)$ & $22(22)$ & $16(3)$ & $20(9)$ & $17(5)$ \\
\hline $\mathrm{DO}_{2}$ & G100 & $294(148)$ & $274(142)$ & 284 (132) & 277 (117) & 285 (149) \\
\hline$\left(\mathrm{ml} \mathrm{minute}{ }^{-1}\right)$ & G60 & 258 (114) & $243(116)$ & $238(108)$ & $226(91)$ & $238(110)$ \\
\hline $\mathrm{VO}_{2}$ & G100 & $69(35)$ & $57(24)$ & $61(33)$ & $52(27)$ & $55(31)$ \\
\hline$\left(\mathrm{ml}\right.$ minute $\left.{ }^{-1}\right)$ & G60 & $61(20)$ & $69(43)$ & $66(35)$ & $56(24)$ & $67(31)$ \\
\hline $\mathrm{TeO}_{2}$ & G100 & $24(6)$ & $22(8)$ & $23(9)$ & $21(12)$ & $20(7)$ \\
\hline$(\%)$ & G60 & $25(8)$ & $28(14)$ & $29(9)$ & $27(12)$ & $29(8)$ \\
\hline HR & G100 & $135(27)$ & $137(27)$ & $130(26)$ & $130(21)$ & $136(21)$ \\
\hline (beat minute $^{-1}$ ) & G60 & $144(35)$ & $139(33)$ & $137(33)$ & $137(33)$ & $139(26)$ \\
\hline MAP & G100 & $101(8) \mathbf{a}$ & $95(10)$ & 95 (10) & $92(10) \mathbf{b}$ & $96(9)$ \\
\hline$(\mathrm{mm} \mathrm{Hg})$ & G60 & 105 (19) & $103(17)$ & $104(18)$ & $101(18)$ & $101(18)$ \\
\hline mPAP & G100 & $8(3)$ & $10(3)$ & $9(3)$ & $9(3)$ & $10(3)$ \\
\hline$(\mathrm{mm} \mathrm{Hg})$ & G60 & $12(4)$ & $11(5)$ & $11(5)$ & $10(5)$ & $10(5)$ \\
\hline PAOP & G100 & $2(3)$ & $2(3)$ & $2(3)$ & $2(3)$ & $2(3)$ \\
\hline$(\mathrm{mm} \mathrm{Hg})$ & G60 & $5(2)$ & $3(3)$ & $3(3)$ & $3(3)$ & $3(3)$ \\
\hline CI & G100 & $4.2(1.6)$ & $3.8(1.3)$ & $4.0(1.0)$ & $3.9(1.0)$ & $3.9(1.3)$ \\
\hline$\left(\mathrm{L}\right.$ minute $\left.\mathrm{e}^{-1} \mathrm{~m}^{-2}\right)$ & G60 & $3.8(1.0)$ & $3.5(0.9)$ & $3.4(0.9)$ & $3.5(0.6)$ & $3.5(0.9)$ \\
\hline SI & G100 & $31(11)$ & $30(10)$ & $31(9)$ & $30(5)$ & $29(8)$ \\
\hline$\left(\mathrm{L}\right.$ beat $\left.{ }^{-1} \mathrm{~m}^{-2}\right)$ & G60 & $27(3)$ & $26(8)$ & $26(7)$ & $26(7)$ & $26(5)$ \\
\hline SVRI & G100 & $2129(802)$ & $2208(738)$ & $1990(526)$ & $1966(458)$ & 2087 (569) \\
\hline$\left(\right.$ dina seg $\mathrm{cm}^{-5} \mathrm{xm}^{-2}$ ) & G60 & $2213(430)$ & $2460(595)$ & $2558(774)$ & $2349(485)$ & $2361(581)$ \\
\hline ICP & G100 & $22(6)$ & $21(6)$ & $22(7)$ & $22(7)$ & $23(8)$ \\
\hline$(\mathrm{mm} \mathrm{Hg})$ & G60 & $18(5)$ & $19(6)$ & $18(4)$ & $17(5)$ & $18(6)$ \\
\hline $\mathrm{CPP}$ & G100 & $79(8)$ & $74(11)$ & $72(11)$ & $70(12)$ & $74(12)$ \\
\hline$(\mathrm{mm} \mathrm{Hg})$ & G60 & $87(21)$ & $85(19)$ & $86(20)$ & $84(20)$ & $83(21)$ \\
\hline \multicolumn{7}{|c|}{$\begin{array}{l}\text { Data are expressed as mean (SD). Means with different upper case letters within each column differ significantly } \\
\text { from one another and means with different lower case letters within each row differ significantly from one another. } \\
\mathrm{PAO}_{2} \text {, alveolar oxygen partial pressure; } \mathrm{AaDO}_{2}, \mathrm{Alveolar} \text { arterial oxygen gradient; } \mathrm{PaO}_{2} / \mathrm{FiO}_{2} \text {, arterial oxygen partial } \\
\text { pressure/inspired oxygen fraction ratio; } \mathrm{PaO}_{2} / \mathrm{PAO}_{2} \text {, arterial-to-alveolar oxygen tension ratio; RI, respiratory index; } \\
\mathrm{DO}_{2} \text {, oxygen delivery; } \mathrm{VO}_{2} \text {, oxygen consumption; TeO } \mathrm{Te}_{2} \text {, oxygen extraction; HR, heart rate; MAP, arterial mean } \\
\text { pressure; mPAP, mean pulmonary arterial pressure; } \mathrm{PAOP} \text {, pulmonary arterial occlusion pressure; CI, cardiac index; } \\
\mathrm{SI} \text {, stroke index; SVRI, systemic vascular resistance index; ICP, intracranial pressure; CPP, cerebral perfusion } \\
\text { pressure. }\end{array}$} \\
\hline
\end{tabular}




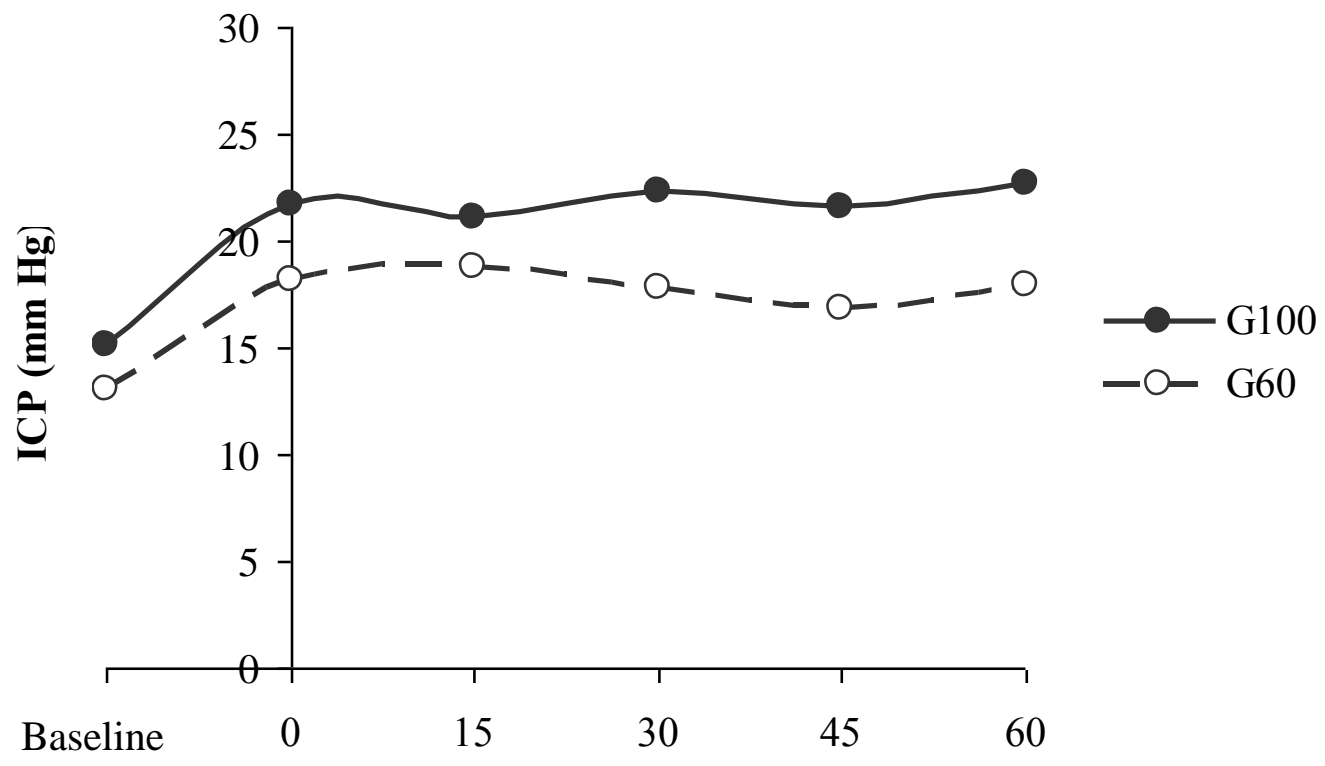

Times

Figure 1. Intracranial pressure (ICP) monitoring in dogs anesthetized with propofol, mechanically ventilated with $\mathrm{FiO}_{2}$ of 1.0 (G100) or 0.6 (G60) and submitted to a temporary obliteration of the right jugular vein. Black filled line and circles represent the group that received $\mathrm{FiO}_{2}=1.0(\mathrm{G} 100)$ and black spotted lines and open circles represent the group that received $\mathrm{FiO}_{2}=0.6(\mathrm{G} 60)$.

Values of $\mathrm{PAO}_{2}$ were significantly different $(\mathrm{P}<0.001)$ between groups throughout the entire procedure (Table 1), but they did not differ among measurements $(\mathrm{P}>0.05)$. With regard to $\mathrm{AaDO}_{2}$, the values in $\mathrm{G} 100$ were higher than the means recorded in $\mathrm{G} 60$ at $\mathrm{T} 0(\mathrm{P}<0.01)$ and at T60 $(\mathrm{P}<0.05)$.

$\mathrm{PaO}_{2} / \mathrm{FiO}_{2}, \mathrm{PaO}_{2} / \mathrm{PAO}_{2}, \mathrm{RI}, \mathrm{Qs} / \mathrm{Qt}, \mathrm{DO}_{2}, \mathrm{VO}_{2}$, $\mathrm{TeO}_{2}, \mathrm{HR}, \mathrm{mPAP}, \mathrm{PAOP}, \mathrm{CI}, \mathrm{SI}, \mathrm{SVRI}$ (Table 1) and CVP did not differ significantly among measurements or between groups $(\mathrm{P}>0.05)$. In G100, MAP at T0 was higher than at T45 $(\mathrm{P}<0.05)$.

\section{DISCUSSION}

Propofol was used in this study because it is known to maintain or decrease the ICP while it maintains the CPP in patients with normovolemia and stable hemodynamics (McKeage and Perry, 2003), hence, it may commonly be selected for patients with suspicious ICP increase (Armitage-Chan et al., 2007).
In patients with increased ICP, the mechanical positive pressure ventilation should be immediately available and instituted at induction, being recommended to maintain the normocapnia (Armitage-Chan et al., 2007; Harvey et al., 2007). Besides, for the initial stage of traumatic brain injury, 100\% oxygen has been indicated (Falcão et al., 2006). In this study, $\mathrm{FiO}_{2}$ of 1.0 was chosen because the $100 \%$ oxygen has been used often during anesthesia procedure (Nunes et al., 2011; Paula et al., 2010). However, in dogs anesthetized with propofol $\left(0.7 \mathrm{mgkg}^{-1}\right.$ minute $\left.^{-1}\right)$ and maintained in spontaneous breathing with different $\mathrm{FiO}_{2}$ (1.0, $0.8,0.6,0.4$ and 0.21 ), authors concluded that $60 \%$ of oxygen should be used (Nunes et al., 2008).

Before occlusion of the jugular vein, ICP values were within the range of values considered normal (Johnston et al., 1991; Plöchl et al., 1998) (Figure 1), but after temporary obliteration of the right jugular vein, ICP increase was clinically significant. From T0, the administration of several $\mathrm{FiO}_{2}$ did not cause 
changes in ICP. The application of mechanical ventilation sought to minimize changes in $\mathrm{PaCO}_{2}$, which can have some direct influence on ICP, CPP and cerebral autoregulation (Harvey et al., 2007; McCulloch et al., 2000).

The normal interval for CPP is between 50 and 150mmHg (Steiner and Andrews, 2006). Hence, in this study, CPP values were within this interval and held constant throughout the entire procedure (Table 1). This stability was attributed to MAP constancy, which is the most important factor in preserving CPP (Sponheim et al., 2003).

$\mathrm{PAO}_{2}$ is often used as an index of the oxygenating efficiency of the lung (Haskins, 2004). In this study, differences between groups (Table 1) can be explained by different $\mathrm{FiO}_{2}$ used, because when an enriched $\mathrm{O}_{2}$ mixture is inspired, the $\mathrm{PAO}_{2}$ rises (Pasetto and Rinaldi, 2004).

Two factors may contribute to changes in $\mathrm{AaDO}_{2}$ : primary ventilation and perfusion mismatch (V/Q) and the decrease of the functional residual capacity (FRC) (Pasetto and Rinaldi, 2004). However, we believe that the difference observed between G100 and G60 (Table 1) was not resultant of FRC decrease, because all dogs were positioned in left lateral recumbency and the propofol rate was the same for the both groups, considering that this drug reduces the contractility of the canine diaphragm (Fujii et al., 2004). Nevertheless, we suggest that V/Q was impaired in G100 when compared to G60.

$\mathrm{PaO}_{2} / \mathrm{PAO}_{2}$ ratio offers a sensible approach to presume the pulmonary shunt (José et al., 2001). The normal value for $\mathrm{PaO}_{2} / \mathrm{PAO}_{2}$ is between 0.74 and 0.90 and, when this parameter is lower than 0.60 , it means that the gas exchange is inefficacious (Kupe and Grant, 1998). Means of $\mathrm{PaO}_{2} / \mathrm{FiO}_{2}$ below $200 \mathrm{~mm} \mathrm{Hg}$ indicated severe Qs/Qt (Goldfarb et al., 1975) and hypoxemia (Kupe and Grant, 1998). However, in this study, the values registered were greater than $500 \mathrm{~mm}$ $\mathrm{Hg}$, which is observed for a normal lung (Haskins, 2004).Thus, in this study, the $\mathrm{PaO}_{2} / \mathrm{FiO}_{2}$ and $\mathrm{PaO}_{2} / \mathrm{PAO}_{2}$ means were within the interval considered normal (Table 1) indicating lung oxygenating efficiency was similar in both groups.
RI is an index of oxygenation function of the lung and its increase reflects the presence of pulmonary shunt in a variety of conditions including atelectasis, pulmonary contusion and pulmonary troboembolism (Goldfarb et al., 1975). During the whole procedure in this study, RI was stable (Table 1) and within the interval considered normal, from 0.1 to 0.37 (Goldfarb et al., 1975) in all groups.

For Qs/Qt no significant difference between G100 and G60 was observed. In normal awake or anesthetized dogs, Qs/Qt may be up to $10 \%$ of the CO (Haskins, 2004). In both groups Qs/Qt means were higher than $10 \%$, which are considered to be increased (Haskins, 2004).

Factors that can change $\mathrm{DO}_{2}$ are: cardiac rhythm, blood pressure, body temperature, $\mathrm{PaO}_{2}, \mathrm{pH}, \mathrm{CO}$ and the quantity of haemoglobin (Mazzaferro, 2009), but, in this study, these parameters were stable, justifying the stability observed to $\mathrm{DO}_{2}$. The use of different $\mathrm{FiO}_{2}$ did not impair $\mathrm{DO}_{2}$, $\mathrm{VO}_{2}$ and $\mathrm{TeO}_{2}$ (Table 1). Oxygen extraction normally ranges between $20 \%$ and $30 \%$ (Haskins, 2004). Thus, in this study, $\mathrm{TeO}_{2}$ means were inside this interval. Besides, the stability of $\mathrm{TeO}_{2}$ can be attributed to $\mathrm{DO}_{2}$ constancy, because when $\mathrm{DO}_{2}$ is decreased, the tissues continue to catch their normal amount of oxygen and, therefore, $\mathrm{TeO}_{2}$ increases (Haskins, 2004).

Regarding HR, the values remained stable in all groups (Table 1), corroborating Nunes et al. (2008), who did not observe significant changes in HR and MAP in propofol-anesthetized dogs during spontaneous ventilation with $\mathrm{FiO}_{2}=1.0$ or $\mathrm{FiO}_{2}=0.6$. Besides, MAP was higher than $80 \mathrm{~mm}$ $\mathrm{Hg}$ (Table 1), suggesting that perfusion was not impaired, because MAP $>65 \mathrm{~mm} \mathrm{Hg}$ is considered sufficient for perfusion maintenance of all vital organs and tissues (Miller, 1986).

The mPAP and PAOP are parameters used routinely in clinical emergency to estimate the left ventricle filling pressure (Mark, 1998) and left atrial pressure, respectively (Greene et al., 1990; Mark, 1998). In normal awake dogs, the $\mathrm{mPAP}$ is $15 \pm 4 \mathrm{mmHg}$ and PAOP is $5 \pm 2 \mathrm{mmHg}$. They are usually decreased by general anesthetics (Haskins, 2007) as it was observed in this study (Table 1). However, no differences between groups or among times were registered. Thus, as described by Nunes et al. (2008), the 
administration of different $\mathrm{FiO}_{2}$ was not able to impair these parameters and consequently ventricular function and preload.

In normal awake dogs, the CI is $4.42 \pm 1.24 \mathrm{~L}$ minute ${ }^{-1} \mathrm{~m}^{-2}$ and it is generally decreased by general anesthetics (Haskins, 2007). The values recorded in all groups (Table 1) were lower than the interval proposed by Haskins (2007), which can be justified by propofol-anesthesia and controlled ventilation. The stability of CI and HR can justify the SI constancy, which is the result of the relation between theses parameters (Shoemaker, 1995). Thus, the various $\mathrm{FiO}_{2}$ used were not able to impair theses parameters.

The SVRI did not differ significantly between groups (Table 1). Considering that SVRI is obtained through mathematical calculation, the registered stability occurred due to the components of equation (MAP, CVP and CI) being stable and did not change with the use of different $\mathrm{FiO}_{2}$. Thus, the influence of these parameters on the systemic vascular resistance index is clear.

\section{CONCLUSION}

In conclusion, in the dogs with high ICP and submitted to continuous infusion of propofol, the cardiopulmonary function was not influenced by the different $\mathrm{FiO}_{2}$ used. Additionally, $\mathrm{FiO}_{2}=1.0$ was not able to aggravate intracranial hypertension.

\section{ACKNOWLEDGEMENTS}

The authors would like to thank the Fundação de Amparo à Pesquisa do Estado de São Paulo FAPESP, for the financial support and scholarships.

\section{REFERENCES}

ARMITAGE-CHAN, E.A.; WETMORE, L.A.; CHAN, D.L. Anesthetic management of the head trauma patient. J. Vet. Emerg. Crit. Care, v.17, p.5-14, 2007.

BAGLEY, R.S.; KEEGAN, R.D.; GREENE, S.A. et al. Pathologic effects in brain after intracranial pressure monitoring in clinically normal dogs, using a fiberoptic monitoring system. Am. J. Vet. Res., v.56, p.1475-1478, 1995.
BRISMAR, B.; HEDENSTIERNA, G.; LUNDQUIST, H. et al. Pulmonary densities during anaesthesia with muscular relaxation: a proposal of atelectasis. Anesthesiology, v.62, p.422-428, 1985.

FALCÃO, A.L.E.; FILHO DANTAS, V.P.; TERZI, R.G.G. Ventilação mecânica em pacientes com traumatismo cranioencefálico grave: controle pela pressão intracraniana e $\mathrm{SjO}_{2}$. In: CARVALHO, C.R.R. (Ed). Ventilação Mecânica Vol. II - Avançado. São Paulo: Atheneu, 2006. p.181-194.

FUJII, Y.; UEMURA, A.; TOYOOKA, H. The recovery profile of reduced diaphragmatic contractility induced by propofol in dogs. Anesth. Analg., v.99, p.99-113, 2004.

GREENE, S.A.; HARTSFIELD, S.M.; TYNER, C.L. Cardiovascular effects of butorphanol in halothane-anesthetized dogs. Am. J. Vet. Res., v.51, p.1276- 1279, 1990.

GOLDFARB, M.A.; CIUREY, T.F.; MCASLAN, T.C. et al. Tracking respiratory therapy in the trauma patient. Am. J. Surg., v.129, p.255-258, 1975.

HÄGGENDAL, E.; JOHANSSON, B. Effects of arterial carbon dioxide tension and oxygen saturation on cerebral blood flow autoregulation in dogs. Acta Physiol. Scand. Suppl., v.66, p.2753, 1965.

HARVEY, R.C.; GREENE, S.A.; THOMAS W. Neurological disease. In: TRANQUILLI, W.J.; THURMON, J.C.; GRIMM, K.A. (Eds). Lumb \& Jones' Veterinary anesthesia and analgesia. 4. ed. Oxford: Blackwell Publising, 2007. p.903913.

HASKINS, S.C. Interpretation of blood gas measurements. In: KING, L.G. (Ed). Textbook of respiratory disease in dogs and cats. 1. ed. Philadelphia: Saunders, 2004. p.181-192.

HASKINS, S.C. Monitoring anesthetized patients. In: TRANQUILLI, W.J.; THURMON, J.C.; GRIMM, K.A. (Eds). Lumb \& Jones' Veterinary anesthesia and analgesia. 4. ed. Oxford: Blackwell Publising, 2007. p.533-558.

HEDENSTIERNA, G.; LUNDQUIST, H.; LUNDH, B. et al. Pulmonary densities during anaesthesia. An experimental study on lung morphology and gas exchange. Eur. Respir. J., v.2, p.528-535, 1989 . 
JOHNSTON, W.E.; VINTEN-JOHANSEN, J.; DEWITT, D.S. et al. Cerebral perfusion during canine hypothermic cardiopulmonary bypass effect of arterial carbon dioxide tension. Ann. Thorac. Surg., v.52, p.479-489, 1991.

JOSÉ, A.; DIAS, E.C.; SANTOS, V.L.A. et al. Predictive value of blood gas analysis and oxygenation score in weaning of mechanical ventilation. Rev. Bras. Ter. Intensiva, v.13, p.5057, 2001.

KUPE, T.J.; GRANT, B.J.B. Arterial blood gas monitoring: respiratory assessment. In: TOBIN, M.J. (Ed). Principles and practice of intensive care monitoring. New York: Mc Graw-Hill, 1998. p.197-215.

MAGNUSSON, L.; SPAHN, D.R. New concepts of atelectasis during general anaesthesia. $\mathrm{Br}$. $J$. Anaesth., v.91, p.61-72, 2003.

MARK, J.B. (Ed). Atlas of cardiovascular monitoring. New York: Churchill Livingstone, 1998. 362p.

MAZZAFERRO, E.M. Postoperative evaluation of the critically ill patient. In: SILVERSTEIN, D.C.; HOPPER, K. (Eds). Small Animal Critical Care Medicine. St. Louis: Saunders Elsevier, 2009. p.626-629.

McCULLOCH, T.J.; VISCO, E.; LAM, A.M. Graded hypercapnia and cerebral autoregulation during sevoflurane or propofol anesthesia. Anesthesiology, v.93, p.1205-1209, 2000.

MCKEAGE, K.; PERRY, C.M. Propofol: a review of this use in intensive care sedations of adults. CNS Drugs, v.17, p.235-272, 2003.

MILLER, E.D. Deliberate hypotension. In: MILLER, E.D. (Ed). Anesthesia. 2. Ed. New York: Churchill Livingstone, 1986. p.1949-1970.

NUNES, N.; LOPES, P.C.F.; SANTOS, P.S.P. et al. Hemodinâmica de diferentes frações inspiradas de oxigênio em cães submetidos à infusão contínua de propofol sob ventilação espontânea. Cien. Rural, v.38, p.729-735, 2008.
NUNES, N.; LEITE, A.V.; PAULA, D.P. et al. Intracranial variables in propofol or sevofluraneanesthestized dogs subjected to subarachnoid administration of iohexol. Arq. Bras. Med. Vet. Zootec., v.63, p.1315-1322, 2011.

PASETTO, A.; RINALDI, L. Total intravenous anesthesia and respiratory system. In: GULLO, A.; BERLOT, G. (Eds). Perioperative and Critical Care Medicine: Educational Issues 2004. New York: Spring, 2004. p.113-122.

PAULA, D.P.; NUNES, N.; NISHIMORI, C.T.D. et al. Efeitos da infusão contínua de propofol ou etomidato sobre variáveis intracranianas em cães. Arq. Bras. Med. Vet. Zootec., v.62, p.302-308, 2010.

PLÖCHL, W.; COOK, D.J.; ORSZULAK, T.A.; DALY, R.C. Critical cerebral perfusion pressure during tepid heart surgery in dogs. Ann. Thorac. Surg., v.66, p.118-124, 1998.

SHOEMAKER, W.C. Diagnosis and treatment of the shock syndromes. In: AYRES, S.M.; GRENVIK, A.; HOLBROOK, P.R.; SHOEMAKER, W.C. (Eds). Textbook of Critical Care. 3. ed. Philadelphia: W.B. Saunders, 1995. p.85-102.

SPONHEIM, S.; SKRAASTAD, O.; HELSETH, E. et al. Effects of 0.5 and 1.0 MAC isoflurane, sevoflurane and desflurane on intracranial and cerebral perfusion pressures in children. Acta Anaesthesiol. Scand., v.47, p.932-938, 2003.

STEINER, L.A.; ANDREWS, J.D. Monitoring the injured brain: ICP and CBF. Brit. J. Anaesth., v.97, p.26-38, 2006.

STURGES, B.K.; LeCOUTEUR, R.A. Intracranial hypertension. In: SILVERSTEIN, D.C.; HOPPER, K. (Eds). Small Animal Critical Care Medicine. St. Louis: Saunders Elsevier, 2009. p.423-429. 